\title{
Mortality risk factors in burn care units considering the clinical significance of acinetobacter infections
}

\author{
Aynur Atilla, M.D., ${ }^{1}$ Leman Tomak, M.D., ${ }^{2}$ Ali Osman Katrancı, M.D., ${ }^{3}$ \\ Alper Ceylan, M.D., ${ }^{4}$ S. Sırrı Kılıç, M.D. ${ }^{1}$ \\ ${ }^{1}$ Department of Infectious Diseases and Clinical Microbiology, Samsun Training and Research Hospital, Samsun; \\ 2Department of Biostatistics, Ondokuzmayis University Faculty of Medicine, Samsun; \\ ${ }^{3}$ Department of Pediatric Surgery, Samsun Training and Research Hospital, Samsun; \\ ${ }^{4}$ Department of General Surgery, Samsun Training and Research Hospital, Samsun
}

\begin{abstract}
BACKGROUND: This study aimed to evaluate risk factors and the role of Acinetobacter isolates in mortality due to burns since morbidity and mortality rates are considerably high.
\end{abstract}

METHODS: A total of four hundred and sixty-five patients hospitalized in our Burn Care Unit between January 2009 and May $201 \mathrm{I}$ were reviewed retrospectively. Logistic regression analysis was used in order to predict the risk.

RESULTS: Mortality rates were as follows: $7.5 \%$ in general, $3.9 \%$ for under 17 years of age, $12 \%$ for between $18-64$ years of age, and $24 \%$ for over 65 years of age $(p<0.001)$.

CONCLUSION: As the burnt body surface area increased, higher mortality rates were detected. Despite higher mortality rates, Acinetobacter infections were not found risk factors for mortality.

Key words: Acinetobacter; burn; infection; mortality.

\section{INTRODUCTION}

Burns are one of the most common and devastating forms of trauma. Improved outcomes for severely burnt patients have been attributed to medical advances in fluid resuscitation, nutritional support, pulmonary care, burn wound care, and infection control practices. Seventy-five percent of all deaths are currently related to sepsis from burn wound infections or other infection complications in patients with severe burns over more than $40 \%$ of Total Body Surface Area (TBSA). [1] Seriously burnt patients have an increased risk for nosocomial infections (NIs) due to the nature of the burn injury itself and $\mathrm{NI}$ is the most common cause of death following

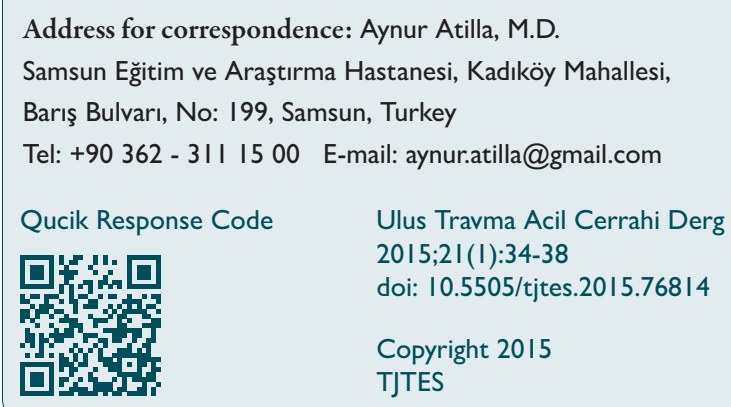

burns. ${ }^{[2]}$ Although recent studies indicate increased role of Acinetobacter infection in mortality in burn patients, some controversy still remains about its exact impact. ${ }^{[3]}$ Due to the increased rate of worldwide resistance and infections, Acinetobacter isolates represent a challenge in the treatment of burns. ${ }^{[4]}$

The data of a total of four hundred and sixty five patients in our burn care unit were reviewed and patients' characteristics and outcome including burn data, infections encountered, pathogens and antibiotic susceptibility tests, infections caused by resistant organisms, risk factors for mortality, and the role of Acinetobacter isolates in mortality were evaluated.

\section{MATERIALS AND METHODS}

This study was conducted at Samsun Education and Training Hospital, a 620-bed hospital with 13 beds reserved for the burn unit. Our burn unit is a tertiary care center serving Northern Turkey, the Black Sea region, with an approximate area population of 5.000.000. The burn unit consists an intensive care unit with 4 beds and 9 single rooms. The electronic medical records database of the burn unit and the file records of Infection Control Committee were searched to identify all patients hospitalized from January 2009 to May 201 I. 


\section{Hospitalization Criteria}

Patients at all ages with second and third degree burns with a TBSA higher than $20 \%$, patients at all ages with third degree burns with a TBSA higher than or equal to $5-10 \%$, burns located on face, ear, or hands and feet, burns of major joints, burns of genital and perineal regions, chemical burns, electrical burns, inhalation injuries, multitrauma accompanying burns, pregnancy and comorbidities (diabetes, hypertension, cardiac disease, immunodeficiency, and etc) were accepted.

NIs were recorded according to Center for Disease Control definitions. ${ }^{[5]}$ TBSA percentage was estimated by using the Wallace's "rule of nines" method ${ }^{[6]}$ and a more accurate assessment was performed especially in children using the Lund and Browder chart. ${ }^{[7]}$

\section{Patient Care}

Routine burn wound care consists of daily cleansing and twice-daily application of topical antimicrobial ointments. In superficial burns, dressings with chlorhexidine impregnated paraffin gauze were applied and changed daily by staff in sterile conditions. In deeper burns, silver sulfadiazine I\% was used. Due to its effect on retardation of wound healing, the use of silver sulfadiazine creams were terminated as soon as epitelization ensued. On admission, in children with TBSA higher than $10 \%$ and in adults with TBSA higher than $20 \%$, early intravenous fluid replacement was initiated. As soon as patients tolerated, enteral feeding took place. Early operative approach was instituted for patients whose burn wounds needed debridement.

The following information was obtained for each admission: age, sex, type of injury, TBSA percentage, Injury Severity Score, comorbidities (including diabetes mellitus, epilepsy, mental retardation, chronic renal failure, hypertension, cerebro vascular accident), duration of stay in hospital and intensive care unit (ICU), NI, causative pathogens, antimicrobial resistance, leukocytosis, albumin level, devices used (ventilator, central line, and urinary catheter days), and survival following hospital discharge. In addition, microbiology records were searched to determine which patients had cultures growing Acinetobacter baumannii. For patients with A.baumannii recovered on culture, charts were further reviewed to determine whether the cultures represented infection or colonization. The bacteriological isolation and antibiotic susceptibility tests were evaluated using the micro Scan auto 4 (Siemens). Clinical and Laboratory Standards Institute criteria were used for the antibiotic susceptibility tests. ${ }^{[8]}$

Multidrug- resistance (MDR) was defined as isolates resistant to at least three drugs in the following classes: $\beta$-lactams, carbapenems, aminoglycosides, and fluoroquinolones. Extensive drug-resistance (XDR) was defined as non-susceptible to at least one agent in all but two or fewer antimicrobial categories (i.e. bacterial isolates remain susceptible to only one or two categories). XDR A. baumannii was defined as resistant to all antimicrobial agents except polymyxins and tigecycline in this study. Pandrug-resistance (PDR) was defined as nonsusceptible to all agents in all antimicrobial categories (i.e. no agents tested as susceptible for that organism). ${ }^{[9]}$

\section{Data Analysis}

The overall rate of Nls was calculated dividing the number of $\mathrm{Nls}$ by the number of patients or by the number of patient days during the study period. Rates of device-related infections were calculated dividing the number of device-related infections by the total number of days that the device was used in the study population as described by NNIS. ${ }^{[10]}$

\section{Statistical Analysis}

Data were analyzed using SPSS 17.0 program and given as numerical (\%) and median (min-max). Logistic regression analysis was used to predict the risk and chi-square test was used in comparison of catherogical variables. Mann-Whitney $U$ test was used to compare both groups with data which did not represent normal distribution. A $p$ value of $<0.05$ was considered statistically significant.

\section{RESULTS}

The records of a total of four hundred and sixty-five patients were available. Mean age of the patients was $18.6 \pm 22.0$ years (median=6.I-87) and two hundred and eighty-two (62.2\%) patients were younger than 18 years of age. Of the patients, two hundred and ninety-two (62.8\%) were female and one hundred and seventy-three (37.2\%) were male. Mean TBSA was $18.0 \% \pm 14.0$ (range $0-95 \%$ ). Percentages of TBSA distribution in patients below and over 18 years of age are presented in Figure I. Cause of injury was recorded in four hundred and thirty-two patients. Of the patients, one hundred and eighty-eight (43.5\%) had scald injury, one hundred and sixteen (26.9\%) had flame injury, forty $(9.3 \%)$ had electrical injury, twenty-seven (6.4\%) had contact injury, and sixty (13.9\%) had liquid injury (hot fluids, boiling jam). No relationship between burn type and $A$. baumannii infection was found $(p>0.05)$.

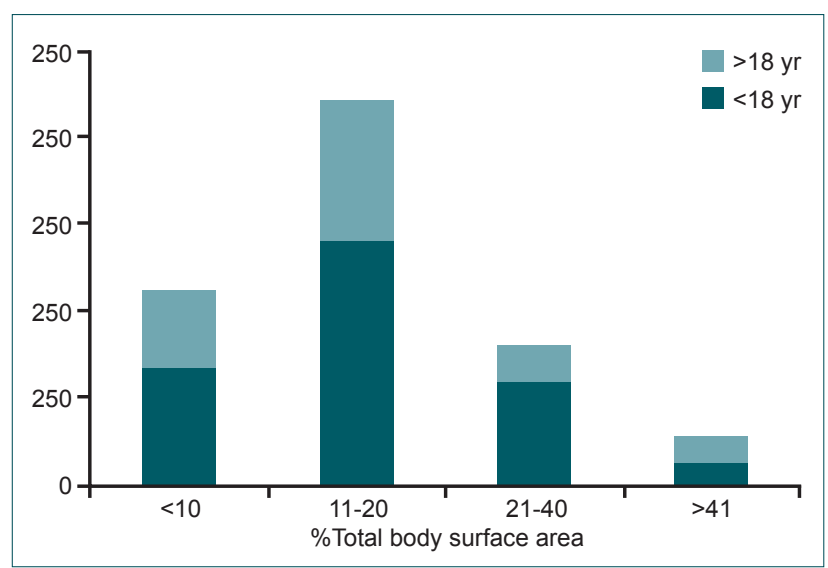

Figure 1. Burn size group (\%Total body surface area) 
Twenty-five patients (5.4\%) had underlying diseases and one hundred and thirty-two patients (28.4\%) underwent surgical corrections. Mean hospitalization period was $18.4 \pm 17.4$ days (median=14, 2-144). Of the patients, hour hundred and five (87.1\%) were noninfected; whereas, sixty (12.9\%) were.

Of the patients, four hundred and thirty (92.5\%) survived; whereas; thirty-five $(\mathbf{7 . 5 \%})$ did not. Mortality rates were as follows: $7.5 \%$ in general, $3.9 \%$ for under 17 years of age, $12 \%$ for between 18-64 years of age, and $24 \%$ for over 65 years of age $(p<0.001)$. Survivors and nonsurvivors were compared considering several parameters. Female: male ratio was 272: 158 and 20: 15 for survivors and nonsurvivors, respectively with statistically no significance $(p>0.05)$. Table I shows the comparison of other parameters. Twenty-four patients had
A. baumanni infections and twelve of them (50\%) died. In five of forty-nine patients colonized with $A$. baumanni, infections caused by this bacteria (10\%) emerged. No significant differences were found considering mortality in patients colonized with Acinetobacter. However, in patients having Acinetobacter infection, mortality was significantly higher $(p<0.00 \mathrm{I})$. Of the patients with TBSA over 4I\%, 64.3\% $(n=18)$ died $(p<0.001)$. As the burnt body surface area increased, higher mortality rates were detected. Logistic regression analysis revealed that Acinetobacter infections were not risk factors for mortality. Logistic regression analysis showed that burnt TBSA, older age, and albumin level were risk factors for mortality (Table I).

A total of one hundred and seven bacterial isolates were obtained. The most predominant bacterial isolate was $A$. bau-

Table I. Patients' characteristics and risk factors of survivors and non-survivors

\begin{tabular}{|c|c|c|c|c|c|c|c|c|c|c|}
\hline \multirow[t]{2}{*}{ Variables } & \multicolumn{2}{|c|}{ Total } & \multicolumn{2}{|c|}{ Survivors } & \multicolumn{2}{|c|}{ Non-survivors } & \multirow[t]{2}{*}{$\mathbf{p}$} & \multicolumn{3}{|c|}{ Logistic regression } \\
\hline & $\mathbf{n}$ & $\%$ & $\mathbf{n}$ & $\%$ & $\mathbf{n}$ & $\%$ & & Odds ratio & $95 \% \mathrm{Cl}$ & $\mathbf{p}$ \\
\hline \multicolumn{11}{|l|}{ Age $(y r)$} \\
\hline$<17$ & 282 & 100 & 271 & 96.1 & 11 & 3.9 & $<0.001$ & I & & \\
\hline $18-64$ & 142 & 100 & 125 & 88 & 17 & 12 & & 0.95 & $0.23-3.86$ & 0.95 \\
\hline$>65$ & 29 & 100 & 22 & 75.9 & 7 & 24.1 & & 5.98 & $1.11-32.20$ & 0.03 \\
\hline \multicolumn{11}{|l|}{ Injuries } \\
\hline Electrical & 40 & 9.3 & 37 & 92.5 & 3 & 7.5 & $<0.001$ & I & & \\
\hline Scald & 188 & 43.5 & 183 & 97.3 & 5 & 2.7 & & 0.29 & $0.02-2.93$ & 0.29 \\
\hline Liquids & 60 & 13.9 & 57 & 95 & 3 & 5 & & 0.31 & $0.02-4.00$ & 0.37 \\
\hline Contact & 61 & 6.4 & 59 & 96.7 & 2 & 3.3 & & 1.2 & $0.09-16.5$ & 0.86 \\
\hline Flame & 116 & 26.9 & 94 & 81 & 22 & 19 & & 1.5 & $0.22-11.18$ & 0.65 \\
\hline TBSA\% & & & & & & & & 1.07 & I.03-I.II & $<0.001$ \\
\hline TBSA $<10$ & 117 & 25.8 & 117 & 100 & 0 & 0 & $<0.001$ & & & \\
\hline TBSA II-20 & 227 & 50.1 & 221 & 97.4 & 6 & 2.6 & & & & \\
\hline TBSA $21-40$ & 81 & 17.9 & 70 & 86.4 & 11 & 13.6 & & & & \\
\hline TBSA >4I & 28 & 6.2 & 1 & 35.7 & 18 & 64.3 & & & & \\
\hline Comorbidity & 25 & 5.4 & 16 & 64 & 9 & 36 & $<0.001$ & & & \\
\hline $\mathrm{NI}$ & 60 & & $4 I$ & 68.3 & 19 & 31.7 & $<0.001$ & & & \\
\hline Acinetobacter infected & 24 & & 12 & 50 & 12 & 50 & $<0.001$ & 4.28 & $0.88-20.84$ & 0.07 \\
\hline Acinetobacter colonized & 49 & & 42 & 85.7 & 7 & 14.3 & $>0.05$ & & & \\
\hline MDR, total & 31 & 51.6 & 18 & 58.1 & 13 & 41.9 & $<0.001$ & 1.97 & $0.47-8.10$ & 0.34 \\
\hline A. baumannii (MDR) & 19 & 57.5 & 9 & 47.4 & 10 & 52.6 & $<0.001$ & & & \\
\hline \multirow[t]{2}{*}{ P. aeruginosa (MDR) } & 12 & 44.4 & 9 & 75 & 3 & 25 & $<0.001$ & & & \\
\hline & \multicolumn{2}{|c|}{$\begin{array}{c}\text { Median } \\
\text { (Min-Max) }\end{array}$} & \multicolumn{2}{|c|}{$\begin{array}{c}\text { Median } \\
\text { (Min-Max) }\end{array}$} & \multicolumn{2}{|c|}{$\begin{array}{c}\text { Median } \\
\text { (Min-Max) }\end{array}$} & $\mathbf{p}$ & & & \\
\hline WBC $\left(10^{3} / \mu \mathrm{L}\right)$ & \multicolumn{2}{|c|}{$14.2(1-48)$} & \multicolumn{2}{|c|}{$13.7(\mid-48)$} & \multicolumn{2}{|c|}{$22.5(4-40)$} & $<0.001$ & & & \\
\hline Albumin (g/dL) & \multicolumn{2}{|c|}{$3.3(0.8-4.7)$} & \multicolumn{2}{|c|}{$3.40 .8-4.7)$} & \multicolumn{2}{|c|}{$2.3(I-3.9)$} & $<0.001$ & 0.20 & $0.08-0.52$ & 0.001 \\
\hline ICU lenght of stay & \multicolumn{2}{|c|}{$0(0-32)$} & \multicolumn{2}{|c|}{$0(0-32)$} & \multicolumn{2}{|c|}{$7(0-17)$} & $<0.001$ & & & \\
\hline
\end{tabular}

TBSA: Total body surface area; NI: Nosocomial infections; ICU: Intensive care unit; MDR: Multidrug- resistant; MDR total: Multidrug-resistant A. baumannii and P. aeruginosa. 
manni 36 (33.6\%), followed by Pseudomonas aeruginosa 27 (25.2\%). Nineteen of the twenty-seven P. aeruginosa isolates (70.3\%) and twenty-nine of the thirty-three A. baumannii isolates (87.8\%) were multidrug resistant. Of the Acinetobacter isolates, fifteen had XDR and in Pseudomonas isolates nineteen had XDR; whereas, none had PDR.

\section{Incidence of Infection}

Sixty $(60 / 465=12.9 \%)$ patients had sixty-eight Nls with an incidence density of 9.9 infections/ 1000 patient days. Burn wound infection $(n=38,55 \%)$ was the most frequent $\mathrm{NI}$. The rates of central vascular catheter, urinary catheter and ventilator usage per 1000 hospitalization days were $0.14,0.15$, 0.02 , respectively. $\mathrm{NI}$ rates related to central vascular catheter, urinary catheter and ventilator usage were 5.I, I.8 and 0 per 1000 invasive device usage days, respectively.

\section{DISCUSSION}

In burn patients, existence of infection, especially sepsis, still remains the most prominent predictive factor affecting mortality and morbidity. Burn injury, reduced immunity, invasive therapeutic and diagnostic procedures, and longer duration of hospitalization are all responsible for serious complications in burn patients. However, Nls are solely the most common cause of death in burns. Evaluating risk factors by assessing microbiological analysis of pathogens and preventive measures, infection control and reducing the incidence of resistance are very important to lead treatment strategies. ${ }^{[2]}$

Considering emerging infection rates as success criteria, our incidence of $\mathrm{NI}$ was $12.9 \%$ and incidence density was $9.9 / 1000$ patient days. It has been apparently known that burnt skin serves as an environment for colonization and infection and subsequently sepsis and possible death. ${ }^{[2]}$ Despite the fact that $\mathrm{NI}$ was not the most important risk factor for mortality in our study, Alp et al. reported infected patients had approximately three times higher mortality rates than uninfected patients. Moreover, advanced age, underlying diseases, and higher TBSA percentage were the most significant risk factors for mortality in the study. ${ }^{\left[{ }^{11}\right]}$ Zarei et al. have found that non-work-related burns, burnt TBSA, and body surface area affected by second- or third- degree burns are independent predictors of mortality. ${ }^{[2]}$

Although variables like age, type of injuries, TBSA percentage, co-morbidity, leukocyte, and serum albumin parameters may have affected mortality, only age over 65, TBSA percentage and serum albumin levels were found to be independent risk factors for mortality. Wang et al. have reported $30 \%$ mortality in patients with TBSA higher than $70 \%$. In addition, burn size, severe inhalation injury, serum creatinine, inotropic support, thrombocytopenia, sepsis, and ventilator dependency have been reported as associated factors for mortality. ${ }^{[13]} \mathrm{Al}$ et al. have found that in addition to some other parameters, hypoalbuminemia and sepsis are important factors for mor- tality. ${ }^{[14]}$ Brusselaers et al. reported in a systematic review of the severe burn injuries in Europe from 1985 to 2009 that burn size and age were the main factors associated with mortality. ${ }^{[15]}$ Church et al. have reported in an excellent review of burn wound infections that burns in the elderly population are more severe and result in a higher number of fatalities. ${ }^{[2]}$ They have also indicated in a recent study assessing factors affecting burn mortality in the elderly population where two hundred and one patients were over 75 years of age that the mortality rate was $47.3 \%$. In our study, mortality rates were found to gradually increase with age, $24 \%$ for over 65 years.

Due to emerging multidrug-resistant organisms mainly as Pseudomonas and Acinetobacter species, infections are associated with significant morbidity and mortality in burn patients. Of special concern, Acinetobacter isolates have been increasingly reported in recent years and have emerged as a significant nosocomial pathogen. ${ }^{[4]}$ The most common microorganism isolated was A. baumannii in our study. As a high prevalance, $33.6 \%$ was in concordance with some reports. Chong et al. have reported $A$. baumannii in fifty-five of ninetyfour patients ${ }^{[16]}$ and Bayram et al. have found fifty-nine of two hundred and fifty isolates to be positive for A. baumannii. ${ }^{[17]}$

Acinetobacter was first considered in the 1970s as an important nosocomial pathogen. Majority of the clinical isolates were susceptiple to most antimicrobials in earlier periods; however, multi-drug resistant isolates have emerged due to extensive use of broad spectrum agents worldwide. ${ }^{[4]}$ Our results revealed that MDR rates were also associated with increased mortality, not emerging as an underlying risk factor. Of the thirty-three patients with Acinetobacter, twenty-nine of them and of the twenty-seven patients with $P$. aeruginosa, nineteen of them represented MDR. Keen et al. reported their experience over a 5-year period that more than half of A. baumannii isolates were multi-drug resistant. ${ }^{[18]}$

Increased mortality rates were detected in Acinetobacter infections $(p<0.001)$; however, this was not regarded a risk factor for mortality (logistic regression analysis). Albrecht et al. have revealed that Acinetobacter infection is associated with burn related mortality and morbidity in a univariate analysis but was not independently associated with death. ${ }^{[3]}$ Recent studies have had mixed results to indicate mortality attributable of Acinetobacter. Some authors reported increased mortality rates secondary to Acinetobacter ${ }^{[19]}$ while others including ours found not. ${ }^{[20]} A$. baumannii isolates common with relatively higher MDR rates may be due to habits of frequent prescribing or using wide spectrum antimicrobials in our country. Besides, some clinical characteristics of A. baumannii isolates, such as its presence in normal skin flora, easier transmissibility and viability in hospital environment due to being multi-drug resistant, may lead to increased incidences of NIs.

Older age, higher TBSA percentage, and albumin level were 
found significant risk factors for mortality. Besides, A. baumannii was not found a risk factor for mortality in our study. However, due to higher rates of mortality occurring in infections by causative microorganisms capable of developing multidrug resistance like $A$. baumannii and $P$. aeruginosa, these microorganisms play an essential role when considering mortality in general.

\section{Conflict of interest: None declared.}

\section{REFERENCES}

1. Rafla K, Tredget EE. Infection control in the burn unit. Burns 2011;37:515. CrossRef

2. Church D, Elsayed S, Reid O, Winston B, Lindsay R. Burn wound infections. Clin Microbiol Rev 2006;19:403-34. CrossRef

3. Albrecht MC, Griffith ME, Murray CK, Chung KK, Horvath EE, Ward JA, et al. Impact of Acinetobacter infection on the mortality of burn patients. J Am Coll Surg 2006;203:546-50. CrossRef

4. Towner KJ. Acinetobacter: an old friend, but a new enemy. J Hosp Infect 2009;73:355-63. CrossRef

5. Horan TC, Andrus M, Dudeck MA. CDC/NHSN surveillance definition of health care-associated infection and criteria for specific types of infections in the acute care setting. Am J Infect Control 2008;36:309-32.

6. American College of Surgeons. Advanced trauma life support.6th ed. Chicago: American College of Surgeons; 1997.

7. Lund CC, Browder NC. The estimation of areas of burns. Surg Gynecol Obstet 1944;79:352-8.

8. Clinical and Laboratory Standards Institute. Performance standards for antimicrobial disc susceptibility tests. CLSI Document M100-S12, 2002. CLSI, Wayne, PA.

9. Magiorakos AP, Srinivasan A, Carey RB, Carmeli Y, Falagas ME, Giske CG, et al. Multidrug-resistant, extensively drug-resistant and pandrug- resistant bacteria: an international expert proposal for interim standard definitions for acquired resistance. Clin Microbiol Infect 2012;18:268-81.

10. National Nosocomial Infections Surveillance System. National Nosocomial Infections Surveillance (NNIS) System Report, data summary from January 1992 through June 2004, issued October 2004. Am J Infect Control 2004;32:470-85. CrossRef

11. Alp E, Coruh A, Gunay GK, Yontar Y, Doganay M. Risk factors for nosocomial infection and mortality in burn patients: 10 years of experience at a university hospital. J Burn Care Res 2012;33:379-85. CrossRef

12. Zarei MR, Dianat S, Eslami V, Harirchi I, Boddouhi N, Zandieh A, et al. Factors associated with mortality in adult hospitalized burn patients in Tehran. Ulus Travma Acil Cerrahi Derg 2011;17:61-5. CrossRef

13. Wang Y, Tang HT, Xia ZF, Zhu SH, Ma B, Wei W, et al. Factors affecting survival in adult patients with massive burns. Burns 2010;36:57-64. CrossRef

14. Al B, Yildirim C, Coban S, Aldemir M, Güloğlu C. Mortality factors in flame and scalds burns: our experience in 816 patients. Ulus Travma Acil Cerrahi Derg 2009;15:599-606.

15. Brusselaers N, Monstrey S, Vogelaers D, Hoste E, Blot S. Severe burn injury in Europe: a systematic review of the incidence, etiology, morbidity, and mortality. Crit Care 2010;14:R188, CrossRef

16. Chong SJ, Ahmed S, Tay JM, Song C, Tan TT. 5 year analysis of bacteriology culture in a tropical burns ICU. Burns 2011;37:1349-53. CrossRef

17. Bayram Y, Parlak M, Aypak C, Bayram I. Three-year review of bacteriological profile and antibiogram of burn wound isolates in Van, Turkey. Int J Med Sci 2013;10:19-23. CrossRef

18. Keen EF 3rd, Robinson BJ, Hospenthal DR, Aldous WK, Wolf SE, Chung KK, et al. Incidence and bacteriology of burn infections at a military burn center. Burns 2010;36:461-8. CrossRef

19. Lortholary O, Fagon JY, Hoi AB, Slama MA, Pierre J, Giral P, et al. Nosocomial acquisition of multiresistant Acinetobacter baumannii: risk factors and prognosis. Clin Infect Dis 1995;20:790-6. CrossRef

20. Blot S, Vandewoude K, Colardyn F. Nosocomial bacteremia involving Acinetobacter baumannii in critically ill patients: a matched cohort study. Intensive Care Med 2003;29:471-5.

\section{KLINIK ÇALIŞMA - ÖZET}

\section{Acinetobacter enfeksiyonlarının klinik önemi ışığında yanık ünitesinde mortalite için risk faktörleri}

\section{Dr. Aynur Atilla, ${ }^{1}$ Dr. Leman Tomak, ${ }^{2}$ Dr. Ali Osman Katrancı, ${ }^{3}$ Dr. Alper Ceylan, ${ }^{4}$ Dr. S. Sırrı Kılıç}

${ }^{1}$ Samsun Eğitim ve Araştırma Hastanesi, Enfeksiyon Hastalıkları ve Klinik Mikrobiyoloji, Samsun;

${ }^{2}$ Ondokuz Mayıs Üniversitesi Tıp Fakültesi, Biyoistatistik Anabilim Dalı, Samsun;

${ }^{3}$ Samsun Eğitim ve Araştırma Hastanesi, Pediatrik Cerrahi Kliniği, Samsun;

${ }^{4}$ Samsun Eğitim ve Araştırma Hastanesi, Genel Cerrahi Kliniği, Samsun

AMAÇ: Morbidite ve mortalite oranlarının yüksek olması nedeniyle yanıklardaki mortalitede risk faktörleri ve Acinetobacter izolatlarının buradaki rolünü değerlendirmeyi amaçladık.

GEREÇ VE YÖNTEM: Ocak 2009'dan Mayıs 20I l'e kadar yanık ünitemizde yatırılarak tedavi edilen toplam 465 hasta geriye dönük olarak gözden geçirildi. Risk belirlenmesinde lojistik regresyon analizi kullanıldı.

BULGULAR: Mortalite oranları genelde \%7.5, 17 yaş altı \%3.9, I8-64 yaş arası \% I2 ve 65 yaş üzeri \%24 idi ( $p<0.00$ I). Total Vücut Yüzey Alanı (TBSA) \%4I'in üzerinde olan hastaların \%64.3'ü (I8 hasta) kaybedildi $(\mathrm{p}<0.00 \mathrm{I})$. TBSA\%, ileri yaş ve albümin seviyeleri mortalitede risk faktörü olarak bulundu. En sık rastlanan bakteriyel izolat Acinetobacter baumanni idi.

TARTIŞMA: Yanık oranları arttıkça mortalite oranlarının da arttığı görüldü. Yüksek mortalite oranlarına rağmen Acinetobacter enfeksiyonları mor talitede risk faktörü olarak bulunmadı.

Anahtar sözcükler: Acinetobacter; enfeksiyon; mortalite; yanık.

Ulus Travma Acil Cerrahi Derg 20I5;2I(I):34-38 doi: 10.5505/tjtes.20I5.768।4 